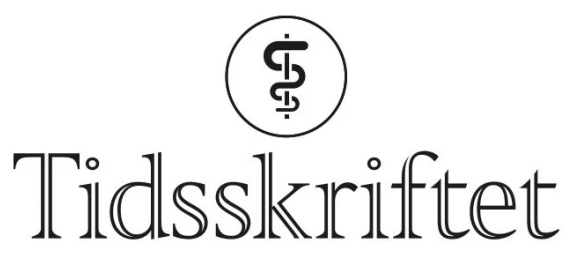

DEN NORSKE LEGEFORENING

\title{
Asymptomatiske smittebærere av sars-CoV-2 i sykehjem
}

DEBATT

\section{KNUT HORDNES}

Knut Hordnes er smittevernoverlege ved Betanien rehabilitering og sykehjem. Forfatteren har fylt ut ICMJE-skjemaet og oppgir ingen interessekonflikter.

\section{KARINA KOLLER LØLAND}

Karina Koller Løland er smittevernoverlege i Bergen kommune. Forfatteren har fylt ut ICMJE-skjemaet og oppgir ingen interessekonflikter.

\section{EGIL BOVIM}

egil.bovim@gmail.com

Egil Bovim er rådgiver i Bergen kommune.

Forfatteren har fylt ut ICMJE-skjemaet og oppgir ingen interessekonflikter.

\section{Overraskende mange sykehjemspasienter kan være asymptomatiske ved påvist smitte med sars-CoV-2. Vi vil dele vår erfaring med smitteoppsporing ved et sykehjem i \\ Bergen.}

Da det ble klart at det var fare for at sykehjemsbeboerne kunne bli utsatt for sars-CoV-2smitte, ble det iverksatt flere tiltak ved det aktuelle sykehjemmet. Fra 16. mars 2020 ble det innført forbud mot besøk til sykehjemsbeboerne. Pålegg og råd fra relevante myndigheter ble ivaretatt så langt som mulig. Dette innebar at ansatte med symptomer på øvre luftveisinfeksjon med varighet to dager eller mer ble testet for koronavirus. En ansatt som hadde hatt symptomer på øvre luftveisinfeksjon, ble testet 17. mars. Etter at negativt prøvesvar forelå, var den ansatte tilbake i tjeneste 24.-29. mars. Vedkommende ble så brått dårlig med hoste, frysninger, ryggsmerter og feber og ble testet igjen 3o. mars. Svaret som forelå neste dag, viste denne gangen positiv test. Den ansatte ble etter dette isolert. En beboer utviklet 3o. mars ukarakteristiske symptomer i form av falltendens, tiltakende forvirring og feber. Beboeren ble testet 31. mars, og laboratoriet rapporterte samme dag at testen var positiv. 
Smittevernkontoret i kommunen ble konsultert. Vi bestemte oss for å teste alle ansatte som hadde vært innom den aktuelle posten de siste 20 dagene, og de øvrige 28 beboerne som ikke var testet. Av ytterligere åtte beboere som testet positivt, var fem symptomfrie og tre hadde kun lette symptomer forenlig med covid-19. Per 6. april er fire av de ni smittede beboerne fortsatt asymptomatiske, mens én har utviklet alvorlig sykdom. Av 6o ansatte testet ytterligere to positivt, én av disse har siden utviklet symptomer.

\section{Hva vi har lært}

På grunn av begrenset kapasitet for testing var anbefalingen fra Folkehelseinstituttet initialt at personer uten symptomer ikke skulle testes (1․). Vår vurdering var at situasjonen ved sykehjemmet tilsa at testing var nødvendig for å kartlegge en situasjon som kunne ha utviklet seg videre. Etter grundig vurdering ble testing av beboere og personalet på posten iverksatt. Resultatet var at 10 av 88 testet positivt. Flertallet av disse hadde ikke symptomer som ble oppfattet som relevante. Rådet fra Folkehelseinstituttet er nå endret. Gjeldende formulering er at "personer uten symptomer skal vanligvis ikke testes». (2). Vi vurderte i vårt tilfelle at testing av asymptomatiske var nødvendig for å få kontroll over smittesituasjonen.

Det finnes asymptomatiske smittebærere av sars-CoV-2, som er årsaken til covid-19 (3). Dette innebærer blant annet at ansatte ved helseinstitusjoner vil kunne videreføre smitte uten at de er klar over at de er smitteførende. Risikoen for smitte av beboere og kolleger må reduseres til et minimum ved at gjeldende rutiner følges og smittevernutstyr benyttes. Vi ser det som svært positivt at det nå er gitt en noe større åpning for testing av symptomfrie personer, og mener det er vesentlig at dette vurderes i situasjoner hvor man kan mistenke at det foreligger symptomfrie smittebærere. Spesielt gjelder dette i situasjoner hvor det er krevende å fullstendig sikre at smitte ikke overføres til personer som har økt risiko for alvorlig forløp av sykdom.

Det er innhentet samtykke til publisering av artikkelen for de to personene som omtales i første avsnitt.

\section{LITTERATUR}

1. Testkriterier for nytt koronavirus (coronavirus), oppdatert 3.4.2020.

http://www.fhi.no/nettpub/coronavirus/helsepersonell/testing-og-diagnostikk-for-nytt-koronaviruscoronavirus Lest 17.4.2020.

2. Testkriterier for nytt koronavirus (coronavirus), oppdatert 5.april 2020.

http://www.fhi.no/nettpub/coronavirus/helsepersonell/testing-og-diagnostikk-for-nytt-koronaviruscoronavirus Lest 17.4.2020.

3. Fakta om viruset og sjukdommen (covid-19), Folkehelseinstituttet, oppdatert 3.april 2020. https://www.fhi.no/nettpub/coronavirus/fakta-og-kunnskap-om-covid-19/fakta-om-koronaviruscoronavirus-2019-ncov/ Lest 17.4.2020.

Publisert: 22. april 2020. Tidsskr Nor Legeforen. DOI: 10.4045/tidsskr.20.0316

Mottatt 7.4.2020, første revisjon innsendt 14.4.2020, godkjent 17.4.2020.

(C) Tidsskrift for Den norske legeforening 2023. Lastet ned fra tidsskriftet.no 26. april 2023. 